\title{
Demoralizacja JAKo POJĘCIE KONTROWERSYJNe. UWAGI NA TLE USTAWY \\ O POSTĘPOWANIU W SPRAWACH NIELETNICH
}

\section{Wprowadzenie w problematykę}

Stwierdzenie przejawów demoralizacji ${ }^{1}$ stanowi jedną $\mathrm{z}$ podstaw interwencji sądu rodzinnego ${ }^{2}$, jaką przewidziano w ustawie z dnia 26 paź-

* Dr, Uniwersytet Zielonogórski; a.kania@wpa.uz.zgora.pl.

1 Według danych, wynikających z Małego Rocznika Statystycznego, przejawy demoralizacji (które stanowiły podstawę dla prawomocnie orzeczonych środków wychowawczych, poprawczych lub kar w sądach powszechnych) stwierdzono u następującej liczby nieletnich: rok 2000 - 8878, rok 2001 - 9441, rok 2002 - 10633, rok 2003 - 12206, rok 2004 - 15193, rok 2005 - 15454, rok 2006 - 16978, rok 2007 - 19503, rok 2008 - 20089, rok 2009 - 18221, rok 2010 - 16118, rok 2011 - 15670, rok 2012 - 15247, rok 2013 - 15184, rok 2014 - 15524. Maty Rocznik Statystyczny, Warszawa 2004, s. 98, Mały Rocznik Statystyczny, Warszawa 2005, s. 99, Maty Rocznik Statystyczny, Warszawa 2006, s. 98, Mały Rocznik Statystyczny, Warszawa 2007, s. 102, Maty Rocznik Statystyczny, Warszawa 2009, s. 101, Mały Rocznik Statystyczny, Warszawa 2010, s. 101, Maty Rocznik Statystyczny, Warszawa 2011, s. 104, Mały Rocznik Statystyczny, Warszawa 2012, s. 106, Mały Rocznik Statystyczny, Warszawa 2013, s. 106, Mały Rocznik Statystyczny, Warszawa 2014, s. 103, Maty Rocznik Statystyczny, Warszawa 2016, s. 86.

${ }^{2}$ V. Konarska-Wrzosek, Zjawisko demoralizacji i przestępczości nieletnich w świetle danych statystycznych, „Acta Universitatis Nicolai Copernici” 1996, z. 307, s. 67 i n.; G. Artymiak, Prawo nieletnich sprawców czynów zabronionych do bezstronnego sądu - zagadnienia wybrane, [w:] A. Michalska-Warias, I. Nowikowski, J. Piórkowska-Flieger (red.), Teoretyczne i praktyczne wspótczesnego prawa karnego. Księga jubileuszowa dedykowana Profesorowi Tadeuszowi Bojarskiemu, Lublin 2011, s. 677; J. Swół, Polski system przeciwdziałania demoralizacji i przestępczości nieletnich. Zarys problematyki, „Przegląd Policyjny” 2014, nr 2, s. 6 i n. W ocenie A. Gaberle, pozostawienie reakcji na naganne zachowania nieletniego, niestanowiące przykładu popełnienia czynu zabronionego, w gestii sądów opiekuńczych albo organów pomocy społecznej oznaczałoby w rzeczywistości tworzenie dwóch różnych postępowań, pomimo że podjęta ingerencja (zarówno w przypadku popełnienia czynu zabronionego oraz 
dziernika 1982 r. o postępowaniu w sprawach nieletnich ${ }^{3}$ (art. 2 u.p.n.). Pomimo doniosłości tego pojęcia dla procesu stosowania niniejszej regulacji prawnej, ustawodawca nie zdefiniował wprost czym jest demoralizacja, poprzestając jedynie na przykładowym wyliczeniu nagannych zachowań nieletniego, mogących świadczyć o zaistnieniu tej przesłanki (art. 4 § 1 u.p.n. $)^{4}$. Przyczynowe ujęcie demoralizacji polegało więc na wskazaniu najbardziej typowych i najczęściej występujących symptomów tego zjawiska. Do wspomnianych, charakterystycznych objawów demoralizacji zaliczono „w szczególności”: naruszanie zasad współżycia społecznego, popełnienie czynu zabronionego, systematyczne uchylanie się od obowiązku szkolnego lub kształcenia zawodowego, używanie alkoholu lub innych środków w celu wprowadzenia się w stan odurzenia, uprawianie nierządu, włóczęgostwo, udział w grupach przestępczych ${ }^{5}$. Powyższy katalog stanowi niewątpliwie egzemplifikację pejoratywnie ocenianych zachowań, których wystąpienie może nie tylko rodzić podejrzenia co do prawidłowego rozwoju społecznego dziecka, ale również - w konsekwencji - zagrażać jego normalnemu funkcjonowania w społeczeństwie. Uzewnętrznienie się tego rodzaju okoliczności powinno więc skłaniać do podjęcia stosownej interwencji wychowawczej6.

Wobec zasygnalizowanych powyżej przejawów demoralizacji warto w tym miejscu zaznaczyć, że wprawdzie etymologia tego słowa nawiązu-

wystąpienia przejawów demoralizacji) opierałaby się na tej samej podstawie, związanej $\mathrm{z}$ nieprawidłowościami w procesie socjalizacji. Por. A. Gaberle, Podstawowe problemy nowej ustawy o nieletnich (na przykładzie projektu ustawy Prawo nieletnich z 2008r., [w:] T. Bojarski, K. Nazar-Gutowska, A. Michalska-Warias, J. Piórkowska-Flieger, A. Sośnicka, M. Szwarczyk, D. Firkowski (red.), Problemy reformy postępowania w sprawach nieletnich, Lublin 2008, s. 21-22. Warto przy tym zwrócić uwagę na regulację art. $15 \S 1$ u.p.n., w którym expressis verbis stwierdzono, że: „Postępowania w sprawach nieletnich prowadzi sąd rodzinny, chyba że przepis szczególny stanowi inaczej".

3 Ustawa z dnia 26 października 1982 r. o postępowaniu w sprawach nieletnich, tekst jednolity Dz. U. z 2016 r., poz. 1654, dalej jako: u.p.n.

${ }^{4}$ Szerzej o teoriach demoralizacji i przestępczości nieletnich zob. B. Urban, Zaburzenia w zachowaniu i przestępczość młodzieży, Kraków 2000, s. 41-72; P. Kozłowski, Dynamika demoralizacji i przestępczości nieletnich - analiza statystyczna zjawiska i propozycja indywidualnych rozwiązań, „Przegląd Więziennictwa Polskiego" 2010, nr 69, s. 103.

${ }_{5}$ Z. Sienkiewicz, Sporne kwestie wokót pojęcia demoralizacji i nieprzystosowania społecznego, [w:] T. Bojarski (red.), Postępowanie z nieletnimi. Orzekanie i wykonywanie środków wychowawczych poprawczych, , Lublin 1988, s. 176.

${ }^{6}$ K. Adamik, M. Lisiecki, Ocena stosowania niektórych środków wychowawczych i poprawczych przewidzianych w ustawie o postępowaniu w sprawach nieletnich, "Przegląd Policyjny" 1997, nr 3, s. 58-59. 
je silnie do problematyki moralności, to jednak ustawowy zakres analizowanego pojęcia obejmuje verba legis sferę zachowań, które nie tylko godzą $\mathrm{w}$ pewne standardy moralno - obyczajowe, ale również w normy etyczne oraz prawne ${ }^{7}$. Jednocześnie należy podkreślić, że większość wskazanych powyżej, rażących przykładów postępowania nieletniego powinna być traktowana w kategoriach sui generis procesu, sekwencji zdarzeń, które ujemnie rzutują na całokształt oceny jego sylwetki ${ }^{8}$. Cechą wspólną wspomnianych zachowań nie jest bowiem sporadyczność, jednostkowość czy incydentalność, lecz ich pewna powtarzalność, czasowa trwałość (z wyjątkiem popełnienia czynu zabronionego), co niewątpliwie potwierdza normatywne brzmienie art. $4 \S 1$ u.p.n. Zaakcentowaną w ten sposób cykliczność potwierdzają konkretne sformułowania ustawowe, w których expressis verbis nawiązano do: "systematycznego" uchylania się od obowiązku szkolnego, „uprawiania” nierządu czy „używania” alkoholu. Trafnie zatem oceniono w judykaturze, że: „Pojedyncze zachowania naganne lub nawet bardzo naganne podejmowane przez nieletniego nie świadczą jeszcze same w sobie o znacznym stopniu demoralizacji. Demoralizacja jest bowiem trwałą tendencją do określonego zachowania - naruszania norm, które są społecznie akceptowane, to wielokrotne, a nie pojedyncze zachowanie odbiegające od przyjętych reguł moralnych" ${ }^{\prime \prime}$.W doktrynie kryminologicznej postuluje się przy tym, aby sądowa reakcja - nawet na tak szczególnie rażące zachowania nieletniego, którym jest popełnienie czynu zabronionego -była każdorazowo ostrożna oraz starannie wyważona. Stosowna decyzja w tym zakresie wymaga bowiem zwrócenia uwagi na szereg okoliczności, pozwalając dopiero po wnikliwej ocenie sytuacji wnioskować o prawdopodobieństwie zaistnienia przejawów demoralizacji u nieletniego ${ }^{10}$.

Warto również nadmienić, że demoralizacja, jako pojęcie ustawowe, posiada charakter stopniowalny. W tym miejscu nie sposób bowiem pominąć, że chociaż rozważana okoliczność stanowi jedną z zasadniczych przesłanek ingerencji sądu rodzinnego, to jednak - zgodnie z art. $3 \S 2$ u.p.n. - w postępowaniu z nieletnimi musi być oceniania według stopnia jej natężenia. Przeprowadzone $\mathrm{w}$ ten sposób wartościowanie nie pozo-

\footnotetext{
${ }^{7}$ M. Korcyl-Wolska, Postępowanie w sprawach nieletnich w Polsce, Kraków 2001, s. 47.

${ }^{8}$ Wyjątkiem w tym zakresie jest ten fragment cytowanego przepisu, który wskazuje na „popełnienie”, a nie „popełnianie” czynu zabronionego (art. 4 § 1 u.p.n. in pricipio).

9 Wyrok SA w Katowicach z dnia 18 marca 2004 r., II AKa 531/03, LEX nr 142829.

${ }^{10}$ J. Błachut, A. Gaberle, K. Krajewski, Kryminologia, Gdańsk 2007, s. 320-321.
} 
staje zaś bez wpływu na rodzaj zastosowanego środka, przewidzianego $\mathrm{w}$ ustawie o postępowaniu $\mathrm{w}$ sprawach nieletnich. $\mathrm{W}$ niniejszej ustawie nie podano przy tym „,żadnych wskaźników mierzalnych”, na których sąd mógłby się oprzeć $\mathrm{w}$ ramach niniejszego procesu ${ }^{11}$. Wychodząc naprzeciw tego rodzaju konieczności, w doktrynie przedmiotu zwrócono uwagę, że przy dokonywaniu gradacji tego pojęcia pomocne byłoby uwzględnienie następujących kryteriów: a) ostrości przejawów demoralizacji, b) częstotliwości i trwałości ich wystąpienia, c) stopnia kumulacji jej przejawów ${ }^{12}$. Powyższe wskaźniki pełnią zatem rolę sui generis niepisanych kwantyfikatorów, do których odwołanie się powinno - przynajmniej w pewnym zakresie - umożliwić dokonanie oceny stopnia nasilenia demoralizacji.

\section{Prawno-socjologiczne ujęcie demoralizacji}

Regulujące, a zatem nadane przez ustawodawcę znaczenie demoralizacji, skłania jednakże do rozważań nad stricte semantycznym rozumieniem

${ }^{11}$ H. Kołakowska-Przełomiec, Postępowanie w sprawach nieletnich, „Państwo i Prawo” 1983, nr 6, s. 48.

${ }^{12}$ K. Gromek, Komentarz do ustawy o postepowaniu w sprawach nieletnich, Warszawa 2004, s. 88. W tym zakresie na uwagę zasługują także poglądy wyrażone w judykaturze: por. wyrok SN z dnia 15 listopada 1984 r., II KR 248/84,OSNKW 1985, nr 7-8, poz. 61: „Stopień demoralizacji może przejawiać się nie tylko przez uprzednie popełnianie przestępstw w ogóle czy popadanie w konflikty z prawem, ale może wyrazić się także w sposobie przygotowania i realizacji tego przestępstwa, które jest aktualnie przedmiotem osądu"; por. także wyrok SN z dnia 4 czerwca 1974 r., III KR 22/74,OSNKW 1974, nr 10, poz. 183: „Na celowość umieszczenia nieletniego w zakładzie poprawczym wskazuje nie tylko wysoki stopień społecznego niebezpieczeństwa czynu, głęboka demoralizacja nieletniego i względy prewencji ogólnej, ale również potrzeba skutecznego wdrożenia nieletniemu szacunku dla prawa i zasad współżycia społecznego, a ponadto szacunku dla nauki i pracy oraz potrzeba nauczenia go zawodu" oraz Wyrok SN z dnia 3 października 1984 r., V KRN, 323/84,OSNPG 1985, nr 3, poz. 48: „Art. 10 ustawy o postępowaniu w sprawach nieletnich jednoznacznie stanowi, że sąd rodzinny może orzec umieszczenie w zakładzie poprawczym jedynie takiego nieletniego, który dopuścił się czynu karalnego w rozumieniu art. 1 $\S 1$ pkt 2 lit ",a" cytowanej ustawy i jest w wysokim stopniu zdemoralizowany", wyrok SA w Katowicach z dnia 18 marca 2004 r., II AKa 531/03, LEX nr 142829: „Tylko obraz całości zachowań nieletniego może wskazywać na jego stopień demoralizacji. Podkreślić też należy, iż nawet charakter i rodzaj popełnionego czynu jest tylko jednym z wyznaczników stopnia demoralizacji nieletniego". 
tego pojęcia ${ }^{13}$. Zgodnie ze słownikowym ujęciem termin ten symbolizuje upadek, odejście od moralności, zepsucie obyczajów, które przejawiają się w nasileniu przestępstw, rozwiązłości, nieuczciwości, korupcji, itp. W roli synonimów wspomnianego określenia często występują takie pojęcia jak: deprawacja, zepsucie, wykolejenie czy niedostosowanie społeczne ${ }^{14}$. $\mathrm{Z}$ powyższego wynika zatem, że demoralizacja jest swoistym procesem „odchodzenia od czegoś”, co w rezultacie mogłoby sugerować, że nieletni rozpoznał znaczenie obowiązujących w społeczeństwie norm, a następnie - z określonych względów - zadecydował o ich nieprzestrzeganiu ${ }^{15}$.Dynamiczna konwencja objaśniania demoralizacji akcentuje tym samym wyrażoną przez nieletniego dezaprobatę wobec uprzednio poznanych i przyjętych wartości moralnych, wskazując jednocześnie na bezskuteczność oraz nietrwałość prawidłowo przebiegającej do tej pory formacji młodego człowieka ${ }^{16}$. Zaprezentowane rozumienie tego terminu nawiązuje zatem do akceptowanych w literaturze kryminologicznej definicji demoralizacji, w których zwraca się uwagę, że stanowi ona niewynikający z przyczyn chorobowych lub rozwojowych stan struktur poznawczych, który sprzyja nierespektowaniu norm moralnych (jak również prawnych) ${ }^{17}$.

${ }^{13}$ S. Lewandowski, H. Machińska, [w:] A. Malinowski (red.), Logika dla prawników, Warszawa 2002, s. 57.

${ }^{14}$ Stownik języka polskiego. T. I, M. Szymczak (red.), Warszawa 1978, s. 379; por. także Praktyczny stownik wspótczesnej polszczyzny. T. 8, H. Zgółowska (red.), Poznań 1994, s. 246 oraz Mały stownik języka polskiego, S. Skorupka, N. Auderska, Z. Łempicka (red.), Warszawa 1969, s. 111. W tym miejscu warto jednak wspomnieć, iż w piśmiennictwie odrębnie opisuje się zjawisko niedostosowania oraz wykolejenia społecznego. W sytuacji bowiem, gdy niechęć do pełnienia ról społecznych wynika z braku skłonności do przestrzegania i aprobowania powszechnie uznanych wartości, wówczas przyjmuje się, że tego rodzaju postać niedostosowania społecznego jest przykładem wykolejenia społecznego. Ponadto, w literaturze zwrócono uwagę na konieczność rozróżnienia samego niedostosowania od nieprzystosowania społecznego. O ile pierwsze $\mathrm{z}$ tych pojęć stanowi łagodniejsza, stosunkowo nietrwałą formę zaburzeń w zachowaniu człowieka, o tyle drugie z nich przybiera już postać silniejszych i trwalszych zakłóceń o charakterze interpersonalnym. Por. E. Bielecki, Wybrane problemy patologii przystosowania społecznego i pedagogiki resocjalizacyjnej, Bydgoszcz 1983; A. Cichy, C. Szyjko, Nieletni jako przestępca w XXI wieku-studium uwarunkowań społeczno-prawnych, Warszawa 2014, s. 19 i 31oraz literatura tam podana; por. także M. Przetacznikowa, M. Susłowska, Wybrane zagadnienia psychologii kliniczno-wychowawczej dzieci i młodzieży, [w:] A. Lewicki (red.), Psychologia kliniczna, , Warszawa 1969, s. 25-254.

${ }^{15}$ E. Bieńkowska, A. Walczak-Żochowska, Postępowanie w sprawach nieletnich. Komentarz, Warszawa 2003, s. 56.

${ }_{16}$ G. Harasimiak, Demoralizacja jako podstawowe pojęcie postępowania z nieletnimi. Analiza i wnioski, Szczecin 2001, s. 114 oraz s. 122-123.

17 J. Błachut, A. Gaberle, K. Krajewski, Kryminologia..., s. 320. 
W kontekście słownikowego znaczenia demoralizacji - kładącego akcent na stricte socjologiczne uwarunkowania tego zjawiska -pojawiają się jednakże wątpliwości czy jej źródeł można również upatrywać w uwarunkowaniach wrodzonych ${ }^{18}$, czyli - inaczej mówiąc - w predyspozycjach genetycznych ${ }^{19}$. Prima facie wydaje się, że narażone a priori na szereg merytorycznych wątpliwości poszukiwanie lombrozowskiego człowieka zbrodniarza, podobnie zresztą jak potencjalnego przestępcy ${ }^{20}$, nie stanowi przekonującego ujęcia problemu. Ponadto, w świetle zaprezentowanego powyżej znaczenia demoralizacja oznacza zniweczenie konstruktywnego, a przede wszystkim pozytywnie przebiegającego procesu socjalizacji, co również podważałoby wartość czynników genetycznych w genezie tego nagannego zjawiska. Z drugiej jednak strony, prezentowany w doktrynie kryminologicznej pogląd, że determinanty ludzkiego zachowania wyznaczają komplementarnie czynniki endogenne oraz egzogenne ${ }^{21}$ nakazywałby zachowanie pewnej ostrożności w ramach formułowania kategorycznych sądów w tym zakresie. W świetle tego poglądu zaburzony stan osobowości nieletniego wymagałby więc starannego przeanalizowania, skoro niekoniecznie musi on stanowić wyłączne następstwo negatywnego oddziaływania środowiska zewnętrznego ${ }^{22}$.

Jednocześnie warto w tym miejscu zaznaczyć, że obok prokryminogennych czynników wrodzonych na uwagę zasługują także w pełni autonomiczne - mniej bądź bardziej uświadomione - decyzje nieletniego o zerwaniu więzi z dotychczasowymi, powszechnie aprobowanymi wartościami. Należy bowiem podkreślić, że podobnie jak respektowanie prawa może

${ }^{18}$ Jak przekonywał jednakże B. Hołyst, rozgraniczenie wpływów genetycznych od wpływów środowiska wychowawczego na proces społecznego niedostosowania jest w praktyce niemożliwe, gdyż trudno określić ich wzajemne relacje. B. Hołyst, Kryminologia, Warszawa 2004, s. 827; por. także A. Siemaszko, Granice tolerancji. O teoriach zachowań dewiacyjnych, Warszawa 1993, s. 108-110.

19 P. Kobes, Prawny system przeciwdziałania demoralizacji i przestępczości nieletnich, Warszawa 2011, s. 113-114. W ocenie A. Krukowskiego: „Przyczyn demoralizacji upatruje się $\mathrm{w}$ czynnikach środowiskowych oraz w uwarunkowaniach (predyspozycjach) genetycznych i wrodzonych nieletniego". A. Krukowski, [w:] A. Krukowski (red.), Ustawa o postępowaniu w sprawach nieletnich. Komentarz, Warszawa 1984, s. 33. Pogląd taki również prezentuje K. Gromek; por. K. Gromek, Komentarz do ustawy..., s. 88.

20 J. Leszczyński, Z problematyki prewencji ogólnej, „Palestra” 1974, nr 11, s. 91.

${ }^{21}$ K. Ostrowska, D. Wójcik, Teorie kryminologiczne, Warszawa 1986, s. 17-18; por. także A. Firkowska- Mankiewicz, Czynniki biopsychiczne a przestępczość nieletnich, Warszawa 1972, s. $184-187$.

${ }^{22}$ C. Czapów, Wychowanie resocjalizujace, Warszawa 1978, s. 140-178 i n. 
wynikać z własnych, przemyśleń (a nie np. z przymusu prawnego), tak samo przy rozważaniu czynników, sprzyjających jego łamaniu nie powinno się abstrahować od indywidualnych skłonności czy też powodów determinujących jego nieprzestrzeganie. Wobec powyższych ustaleń, można by zatem stwierdzić, że zaprezentowane określenie demoralizacji opiera się na sui generis domniemaniu, że: „(...) ktoś był moralny, lecz następnie uległ zepsuciu" z przyczyn tkwiących w nim samym lub na skutek wpływów zewnętrznych" 23 .

Posługiwanie się stricte semantycznym znaczeniem analizowanego terminu może więc wzbudzać pewne wątpliwości, skoro nakazuje ono de facto przyjąć, iż każde dziecko może osiągnąć w ramach procesu wychowawczego taki poziom socjalizacji, że jest w stanie rozpoznać - ogólnie ujmując - co jest dobre, a co jest złe ${ }^{24}$. Tego rodzaju przypuszczenie nie aktualizuje się bowiem zwłaszcza w odniesieniu do małych dzieci, których postawy społeczne, poglądy moralne oraz system wartości podlegają następującym po sobie etapom kształtowania ${ }^{25}$. W literaturze podkreśla się przy tym, że sama świadomość obowiązku przestrzegania określonych zasad społecznie oczekiwanych nie jest per se wystarczająca. W równie doniosłym stopniu okazuje się bowiem zinternalizowanie tych wartości oraz umiejętność zgodnego z nimi postępowania ${ }^{26}$.

Ponadto, w doktrynie przedmiotu zwrócono uwagę na pejoratywne zabarwienie pojęcia demoralizacji, co sugerowałoby, że za następstwa prawnie nieakceptowanych postępowań obciąża się - w sposób niejako automatyczny - dziecko. Jednostronnie stygmatyzujący charakter wspomnianego terminu ${ }^{27}$ prowadziłby $\mathrm{w}$ ten sposób do pominięcia przypadków, w których nieletni mógłby okazać się nie sprawca, ale ofiarą zachowań dewiacyjnych ${ }^{28}$. Negatywną postawę społeczną nieletniego mogą bowiem determinować okoliczności, na które on nie ma wpływu. W piśmiennictwie podkreśla się, że szczególnie osoby funkcjonujące $\mathrm{w}$ ramach Łzw. trudnych rodzin, w których postawy rodziców cechowało emocjo-

${ }^{23}$ A. Strzembosz, Postępowanie w sprawach nieletnich w prawie polskim, Lublin 1984, s. 33.

${ }^{24}$ Ibidem.

25 A. Laskowski, A. Rejzner, E. Tokarczyk, Demoralizacja i przestępczość dzieci i młodzie$\dot{z} y$. Atlas, Warszawa 1996, s. 5.

${ }^{26}$ B. Kowalska-Ehrlich, Młodzież nieprzystosowana społecznie a prawo, Warszawa 1988, s. 18.

27 P. Górecki, S. Stachowiak, Ustawa o postępowaniu w sprawcach nieletnich. Komentarz, Warszawa 2010, s. 18.

${ }^{28}$ Ibidem, s. 17. 
nalne odrzucenie i wadliwy system wychowawczy są częściej narażone na nieprzystosowane społecznie. Na tej podstawie można by w konsekwencji stwierdzić, że nasilenie nieprawidłowych postaw rodzicielskich stwarza niewątpliwie wyższy stopień zagrożenia demoralizacją dzieci i młodzieży ${ }^{29}$. Mówiąc więc o zaniedbaniu moralnym czy też o braku wychowania moralnego wypada w sposób szczególny zwrócić uwagę na destrukcyjny wpływ czynników egzogennych, które uniemożliwiły prawidłowy przebieg uspołecznienia ${ }^{30}$. Dzieci moralnie zaniedbanych - czyli takich, które nie miały w ogóle bądź posiadały nieodpowiednie wzorce środowiskowe - nie należy przy tym określać mianem osób amoralnych bądź też społecznie upośledzonych, gdyż takie sformułowania mogłyby błędnie wskazywać, że żadna akcja reedukacyjna w ich przypadku nie przyniesie spodziewanych rezultatów ${ }^{31}$.

Powyższa konstatacja nakazuje jednocześnie zastanowić się - czy pozostawanie $\mathrm{w}$ środowisku, wykazującym niski poziom kultury oraz aprobującym, jak również popularyzującym działania aspołeczne (oparte przykładowo na: przemocy, dyskryminacji czy wyzysku), pozwala na rozwój zachowań prospołecznych? ${ }^{32} \mathrm{~W}$ literaturze przedmiotu wyrażono bowiem przekonanie, że sui generis „środowiskowej dewiacji," charakteryzującej się nieprawidłowym ukształtowaniem stosunków społecznych, przypada nierzadko poważny udział w społecznym upośledzeniu jednostki, która obserwując określone zachowania patologiczne, przejmuje

${ }^{29}$ J. Szmiłyk, Przeciwdziałanie demoralizacji dzieci i młodzieży w świetle przepisów ustawy o postępowaniu $w$ sprawach nieletnich, www.google.pl/url? sa=tE $r c t=j \mathcal{E} q=\mathcal{E}$ es $r c=s \mathcal{E}$ source $=w e b \mathcal{E} c d=4 \mathcal{E} v e d=w 0 C D w Q F j A D \mathcal{E} u r l=\mathrm{http} \% 3 \mathrm{~A} \% 2 \mathrm{~F} \% 2 \mathrm{Fwww} \cdot$ eduforum.pl\%2Fmodules. php\%3Fname\%3DPublikacje\%26d_op\%3Dgetit\%26lid\%3D2867\&ei=PIUAU7X5C6r9yw PZ0IHQCg\&usg=AFQjCNHUbUUDvL9iywB1nVkeaoGMIRLw\&bvm=bv.61535280,d. bGQ, dostęp 02.07.2015 r.; por. także uwagi H. Kołakowskiej-Przełomiec, w świetle których autorka zwróciła uwagę, iż: „Środowisko rodzinne odgrywa pierwszoplanową rolę $\mathrm{w}$ wychowaniu dziecka (...). Istotne więc zagadnienie w problematyce nieprzystosowania i przestępczości nieletnich stanowią ogólne warunki i całokształt atmosfery wychowawczej w rodzinie". H. Kołakowska-Przełomiec, Zagadnienie profilaktyki przestępczości nieletnich w świetle badań kryminologicznych, "Studia Prawnicze” 1972, nr 34, s. 85-86.

30 Z. Ostrihańska, Kryteria nieprzystosowania społecznego dzieci i młodzieży, "Archiwum Kryminologii" 1972, nr 5, s. 15.

31 J. Konopnicki, Niedostosowanie społeczne, Warszawa 1971, s. 25; por. także J. Konopnicki, Powodzenia i niepowodzenia w szkole, Warszawa 1966, s. 88-89.

${ }^{32}$ Z. Skorny, Koncepcje socjalizacji w literaturze naukowej, „Psychologia Wychowawcza” 1975, nr 3, s. 379. 
oraz utrwala destruktywne cechy osobowościowe ${ }^{33}$. W następstwie tego rodzaju zakłóceń, godzących $\mathrm{w}$ sferę prawidłowego przebiegu procesu uspołecznienia pojawiają się określonego rodzaju defekty socjalizacyjne, których typologię oddaje zestawienie, opracowane przez J. Toby ${ }^{34}$. Zdaniem autora, za powstanie swoistego "niedostosowania społecznego" jednostki ${ }^{35}$, odzwierciedlającego w konsekwencji swoisty konflikt pomiędzy jej nieukształtowaną osobowością a społeczeństwem, może być odpowiedzialna w szczególności: 1) socjalizacja niewystarczająca, która stanowi rezultat zaburzeń, pojawiających się w procesie interakcji, zachodzącym pomiędzy osobą socjalizującą a osobą socjalizowaną 2) socjalizacja niewłaściwa, polegająca na przekazywaniu osobie socjalizowanej norm „podkulturowych” - czy też inaczej mówiąc - wzorców, wywodzących się ze sfery tzw. marginesu społecznego, 3) socjalizacja ambiwalentna, której istotę odzwierciedla antagonistyczny wpływ na jednostkę różnych środowisk społecznych (np. odmienność norm przekazywanych w rodzinie i odmienność norm dostarczanych w środowisku rówieśniczym ${ }^{36}$.

Zaprezentowane powyżej, najważniejsze przeszkody, godzące w prawidłowy rozwój jednostki, pozwalają stwierdzić, że kontrsocjalizujący wpływ społeczny może stanowić dogodną płaszczyznę dla kształtowania się zachowań patologicznych ${ }^{37}$. Stąd też wydaje się, że nietrafne byłoby obciążanie nieletnich za tego rodzaju uwarunkowania środowiskowe. Nie

33 A. Makowski, Niedostosowanie społeczne młodzieży i jej resocjalizacja, Warszawa 1994, s. 19-21.

${ }^{34}$ Powołaną typologię socjalizacji omawiam za: A. Kossowska, Funkcjonowanie kontroli społecznej, analiza kryminologiczna, Warszawa 1992, s. 106-107.

${ }^{35}$ Jak trafnie podnieśli I. Niewiadomska oraz P. Polakiewicz, najbardziej skrajną formą niedostosowania społecznego stanowi przestępczość, czyli popełnienie czynu, godzącego w ukształtowany porządek w państwie. Por. I. Niewiadomska, P. Polakiewicz, Osobowość sprawcy a popetnienie przestępstwa, [w:] J. Świtka, M. Kuć, I. Niewiadomska (red.), Osobowość przestępcy a proces resocjalizacji, Lublin 2005, s. 41.

${ }^{36}$ Za: A. Kossowska, Funkcjonowanie kontroli..., s. 106-107; por. także M. Derlatka, Przestępczość jako skutek wadliwej socjalizacji w rodzinie, "Jurysta” 2013, nr 2, s. 26 i n.; A. Tyburska, Wpływ dysfunkcyjności rodziny na rozwój dzieci i młodzieży, "Przegląd Policyjny” 1997, nr 4 , s. 36 i n.

37 A. Gaberle, Patologia społeczna, Warszawa 1993, s. 175-176. Do głównych przejawów, świadczących o kontrasocjalizacji cytowany autor zaliczył: 1) postawę nihilistyczną polegającą na odrzuceniu wszelkich wartości poza czerpaniem własnych korzyści oraz przyjemności, 2) internalizację wartości sprzecznych z wartościami, charakterystycznymi dla danego kręgu kulturowego, 3) usprawiedliwianie zachowań społecznopatologicznych, 4) nawyki w działaniach, zwiększające prawdopodobieństwo wystąpienia zjawisk społecznopatologicznych, 5) sytuacyjne bądź podmiotowe ograniczenie zakresu wartości, szanowanych w danym kręgu kulturowym. 
bez racji podniesiono zatem w piśmiennictwie, że pojęcie „demoralizacja" może niekiedy mylnie sugerować, że podjęcie stosownej interwencji związane jest z zachowaniem nieletniego, podczas gdy faktycznym problemem pozostaje stworzenie bądź przywrócenie właściwego funkcjonowania jego środowiska wychowawczego ${ }^{38}$.

Zasygnalizowany problem aktualizuje się zwłaszcza w sytuacji, gdy należy dokonać rozgraniczenia spraw podlegających rozpoznaniu $\mathrm{w}$ postępowaniu opiekuńczym (według przepisów ustawy z dnia 17 listopada 1964 r. - Kodeks postępowania cywilnego ${ }^{39}$ ) oraz spraw nieletnich rozpoznawanych w trybie ustawy o postępowaniu w sprawach nieletnich. Należy bowiem wspomnieć, że sąd rodzinny może oddziaływać nie tylko na nieletniego, ale - działając jako sąd opiekuńczy - może również podjąć stosowne czynności wobec rodziców lub opiekunów, jeżeli dojdzie do wniosku, że dobro dziecka jest zagrożone ${ }^{40}$. Jak przekonywał zaś W. Patulski, linia demarkacyjna, oddzielająca postępowanie z nieletnimi od postępowania opiekuńczego, dotyczącego ingerencji we władzę rodzicielską jest przy tym „niezbyt ostra”. Z zaprezentowanych przez autora poglądów wynikało bowiem, że w praktyce "przejawy demoralizacji” będzie można odnieść do „starszych nieletnich”, których rodzicom bądź opiekunom nie będzie już można zarzucić niedopełnienia obowiązków, wynikających z władzy rodzicielskiej bądź opiekuńczej ${ }^{41}$.

W ramach zastrzeżeń wysuniętych wobec pojęcia demoralizacji należy również zwrócić uwagę, że niektóre objawy - świadczące o rzekomym jej zaistnieniu - nie powinny per se podlegać tak rygorystycznej interpretacji. W doktrynie podkreśla się, że "łamanie” czy „omijanie” niektórych zasad współżycia społecznego jest niekiedy zjawiskiem normalnym z punktu widzenia psychologii rozwojowej i nie musi od razu stwarzać zagrożenia dla interesów społecznych czy indywidualnych ${ }^{42}$. Również powszechne

${ }^{38}$ M. Stanowska, A. Walczak-Żochowska, K. Wierzbowski, Uwagi o profilu ustawy o postępowaniu z nieletnimi. (Zagadnienia materialnoprawne i procesowe), „Państwo i Prawo” 1983, nr 6, s. 53.

${ }^{39}$ Ustawa z dnia 17 listopada 1964 r. - Kodeks postępowania cywilnego, tekst jednolity Dz. U. z 2016 r., poz. 1822. 36.

${ }^{40}$ K. Eichstaedt, Postepowanie przed sadem w sprawach nieletnich, Warszawa 2008, s. 35-

${ }^{41}$ W. Patulski, Postepowanie w sprawach nieletnich, "Nowe Prawo" 1983, nr 1, s. 10; por. także B. Stańdo-Kawecka, Prawo karne nieletnich - od opieki do odpowiedzialności, Warszawa 2007, s. 311-312.

42 A. Ratajczak, Materialnoprawne problemy ustawy o postępowaniu w sprawach nieletnich, „Państwo i Prawo” 1983, nr 2, s. 10. 
traktowanie np. ucieczek z domu, wagarowania w kategoriach przejawów demoralizacji może okazać się chybione. Powody takiego zachowania posiadają w istocie różnorodne podłoża, związane np. z konfliktem między rodzicami czy niesprawiedliwym traktowaniem w szkole. ${ }^{43}$ Należy zatem podkreślić, że wystąpienie niektórych ustawowo zadekretowanych przejawów demoralizacji nie zawsze świadczy o jej faktycznym zaistnieniu. W konsekwencji wypada więc zaznaczyć, że w rzeczywistości nie należy stawiać znaku równości pomiędzy „przejawami” demoralizacji a samą demoralizacją ${ }^{44}$ Z zaprezentowanego ujęcia wynika tym samym, że poszukiwania symptomów demoralizacji nie powinno się sprowadzać do samej oceny zewnętrznych zachowań nieletniego. Wydaje się bowiem, że w tym zakresie wymagane byłoby również uwzględnienie stanu osobowości nieletniego, odznaczającego się negatywnym nastawieniem wobec postaw oraz wartości społecznie aprobowanych ${ }^{45}$.

Z powyższych ustaleń wynika, że schematyczne, a przy tym przebiegające in abstracto, utożsamianie każdej z okoliczności wymienionej $\mathrm{w}$ art. $4 \S 1$ u.p.n. $\mathrm{z}$ demoralizacją prowadziłoby niekiedy wręcz do absurdalnych rozstrzygnięć. Interdyscyplinarne znaczenie tego ostatniego pojęcia, nawiązujące silnie do sfery psychologii, pedagogiki, psychiatrii czy socjologii, nakazuje tym samym przyjąć bardziej elastyczną wykładnię cytowanego przepisu. Oznaczałoby to w konsekwencji, że wymienione w nim okoliczności z reguły moga ale jednocześnie nie muszą świadczyć o demoralizacji $\mathrm{w}$ konkretnym przypadku ${ }^{46}$. Nie usprawiedliwiając jakkolwiek zachowań wypełniających znamiona demoralizacji, warto również zaznaczyć, że wykładnia tego pojęcia powinna także uwzględniać określony kontekst sytuacyjny. Jak przekonywał M. Cieślak: „Powszechność pewnego zjawiska pobudza instynkt naśladownictwa, osłabia hamulce i wytwarza coś w rodzaju normy obyczajowej. W grupie społecznej niełatwo jest być odmieńcem. Sędziowie dla nieletnich wiedzą że zdarza-

${ }^{43}$ M. Stanowska, A. Walczak-Żochowska, K. Wierzbowski, Uwagi o profilu ustawy..., s. 53.

${ }^{44}$ V. Konarska-Wrzosek, Prawny system postępowania z nieletnimi, Warszawa 2013, s. 58-59.

${ }^{45}$ Z. Sienkiewicz, System sądowych środków wobec nieletnich w prawie polskim, Wrocław 1989, s. 93.

${ }^{46}$ Z. Sienkiewicz, Sporne kwestie wokót pojęcia demoralizacji i nieprzystosowania społecznego, [w:] T. Bojarski (red.), Postępowanie..., s. 177 i 179; por. także V. Konarska-Wrzosek, Ochrona nieletnich przed demoralizacja i przestępczościa w ujęciu ustawy o postępowaniu w sprawach nieletnich, „Państwo i Prawo” 1999, nr 5, s. 52. 
ją się wypadki, w których dzieci kradną tylko dlatego, żeby nie wydać się gorszymi (mniej zaradnymi lub odważnymi) w oczach swoich kolegów, choć dobrze wiedza, że tego robić nie wolno" ${ }^{47}$. To właśnie wzmożona częstotliwość określonych, bezprawnych zachowań, „stępia ostrze” ich ujemnej oceny, przyczyniając się samoistnie do niedającej się uniknąć demoralizacji społeczeństwa ${ }^{48}$.

\section{Ustawowe przejawy demoralizacji i związane $\mathrm{z}$ nimi kontrowersje}

Nie aspirując $w$ ramach niniejszego opracowania do kompleksowej analizy wyróżnionych $\mathrm{w}$ ustawie przejawów demoralizacji oraz związanych z nimi trudności interpretacyjnych, warto jednak zasygnalizować, że niektóre z symptomów tego zjawiska rodzą szczególne wątpliwości. Sugerowane $\mathrm{w}$ ten sposób uwagi krytyczne dotyczą przede wszystkim ratio legis normatywnej przesłanki, w której expressis verbis odwołano się do bliżej nieskonkretyzowanych zasad współżycia społecznego. Zgodnie bowiem $\mathrm{z}$ art. $4 \S 1$ u.p.n., ich naruszenie stanowi - w pełni samodzielną - podstawę interwencji sądu rodzinnego, podejmowaną w trybie niniejszej ustawy. Pojawiające się $\mathrm{w}$ tym zakresie wątpliwości interpretacyjne wynikają przy tym nie tylko z ideologiczno-politycznego zabarwienia wspomnianego zwrotu ${ }^{49}$, lecz także są one związane z typowymi zastrze-

${ }^{47}$ M. Cieślak, Wytyczne Sądu Najwyższego w sprawie wymiaru kary a problem społecznego niebezpieczeństwa (w zwiazku z głosem sędziego Szerera), „Palestra” 1958, nr 7-8, s. 81. W tym miejscu warto również wspomnieć o argumentacji, zaprezentowanej przez P. Sztompkę, w której autor stwierdził, że: „Gdy przestrzegamy zakazów, nic nas złego nie spotka, ale nie możemy tez liczyć na szczególne nagrody. Ciekawe, że nie ma tu symetrii z sytuacją poprzednia, i gdy zakazy są z kolei powszechnie łamane, to sam fakt ich konsekwentnego przestrzegania nie tylko nie może nam przynieść pochwały, uznania czy sławy, ale przeciwnie, często sprowadza odium dziwaka, naiwniaka i łajzy". Por. P. Sztompka, Socjologia. Analiza społeczeństwa, Kraków 2002, s. 261.

${ }^{48}$ M. Cieślak, O wytycznych Sądu Najwyższego z 16.X. 1957 r. w sprawie wymiaru kary, „Palestra" 1958, nr 3-4, s. 8.

49 S. Dmowski, S. Rudnicki, Komentarz do kodeksu cywilnego. Ksiega pierwsza. Część ogólna, Warszawa 2007, s. 37. W ocenie Z. Radwańskiego oraz M. Zielińskiego, występująca w przepisach ustawy z dnia 23 kwietnia 1964 r. - Kodeksu cywilnego (tekst jednolity, Dz.U. z 2016 r., poz. 380) klauzula zasad współżycia społecznego nie powinna być interpretowana przez pryzmat polityczno-ideologicznych odniesień, związanych z ustrojem PRL. W przekonaniu autorów, wspomniana klauzula generalna nawiązuje silnie do war- 
żeniami, jakie kieruje się wobec klauzul generalnych ${ }^{50}$. Integralną cechą tego rodzaju wyrażeń ocennych, odsyłających do systemu wartości pozaprawnych, pozostaje bowiem ich: otwartość, ogólnikowość oraz enigmatyczność ${ }^{51}$.Niezależnie zaś od normatywnego ${ }^{52}$ bądź sytuacjonistycznego ${ }^{53}$ ujmowania zasad współżycia społecznego, wydaje się, że zawsze przy próbie ich określenia występuje szeroka swoboda interpretacyjna. Wobec powyższej konstatacji pojawia się zatem pytanie - czy w regulacji, kreującej podstawy postępowania wobec nieletnich, powinna znaleźć odzwierciedlenie klauzula generalna? Można bowiem wyrazić wątpliwość czy tak szeroka otwartość norm, odnosząca się bezpośrednio do samych podstaw stosowania niniejszej ustawy, jest prawidłowym zabiegiem legislacyjnym oraz, czy nie godzi w wyrażone w preambule niniejszej regulacji dobro nieletniego? Pozwolenie na stosowanie wnioskowania extra legem jest bowiem równoznaczne z zaakceptowaniem sytuacji, że w ten sposób nawiązuje się nie tylko do normy poddanej wykładni, lecz także do innych jeszcze wartości, w pewien sposób powiązanych z interpretowaną normą ${ }^{54}$. Poza tym, analizowana klauzula wzbudza zastrzeżenia również z innego

tości, na które wskazuje obowiązująca Konstytucja Rzeczypospolitej Polskiej z 1997 r. Por. Z. Radwański, M. Zieliński, [w:] M. Safjan (red.), System Prawa Prywatnego. Prawo cywilne - część ogólna. Tom I, Warszawa 2012, s. 396.

${ }^{50}$ Klauzule generalne należy przy tym odróżnić od zwrotów niedookreślonych, które nie są klauzulami generalnymi. O ile bowiem te pierwsze odsyłają do ocen, o tyle te drugie wymagają kwalifikowania wielkości, np. ważny interes dziecka (przykład ten de facto zwiera zarówno klauzulę generalną jak również zwrot niedookreślony). Por. A. Chodun, A. Gomułowicz, A. Skoczylas, Klauzule generalne i zwroty niedookreślone w prawie podatkowymi administracyjnym. Wybrane zagadnienia teoretyczne i orzecznicze, Warszawa 2013, s. 31.

${ }^{51}$ Por. S. Grzybowski, Struktura i treść przepisów prawa cywilnego odsyłajacych do zasad współżycia społecznego, "Studia Cywilistyczne” 1965, nr 6, s. 25 i n.; J. Nowacki, Luki w prawie. Ideologia, "Studia Prawno-Ekonomiczne” 1970, t. VI, s. 39 i n.; K. Wójcik, Klauzule generalne jako zwroty wieloznaczne i oceny, "Studia Prawno-Ekonomiczne" 1988, t. XLI, s. 39.

${ }^{52}$ Normatywne ujęcie zasad współżycia społecznego wskazuje, iż zasady te są normami o uzasadnieniu aksjologicznym, które należą do obowiązującego prawa. Są to - jak zaznacza się - normy moralne, jak również normy obyczajowe. Por. A. Szpunar, Stosowania art. 5 Kodeksu cywilnego w sprawach o prawa stanu, „Państwo i Prawo” 1981, nr 6, s. 57; por. także T. Dybowski, Zasady współżycia społecznego i społeczno-gospodarcze przeznaczenia prawa a prawo własności, „Nowe Prawo” 1967, nr 6, s. 723.

${ }^{53}$ Sytuacjonistyczne ujęcie zasad współżycia społecznego wskazuje na ich wyjątkowość oraz konieczność zrelacjonowania oceny sędziowskiej do indywidualnego przypadku. Por. L. Krakowski, Zasady wspótżycia społecznego w stosunkach prawa pracy w PRL, Warszawa 1970, s.77 i n.

${ }^{54}$ Por. uwagi K. Wójcik; K. Wójcik, Klauzule generalne a pojęcia prawne i prawnicze (zasady prawa i społeczne niebezpieczeństwo czynu), "Studia Prawno-Ekonomiczne” 1990, t. XLV, s. 70 i n. 
względu. Należy bowiem zaznaczyć, że w świetle art. $4 \S 1$ u.p.n. przykładu naruszenia zasad współżycia społecznego nie stanowiłyby pozostałe, wymienione $w$ tym przepisie przejawy demoralizacji. Tymczasem wydaje się, że wymienione w cytowanym przepisie, pozostałe naganne zachowania nieletniego mogą z powodzeniem zostać ocenione jako uchybiające powszechnie aprobowanym zasadom współżycia społecznego.

Warto również nadmienić, że - jak dotąd - nie wypracowano katalogu wspomnianych zasad, których naruszenie uzasadniałoby ingerencję sądu rodzinnego. Odwołując się w tym miejscu do dorobku doktryny prawa cywilnego, wypada jednakże zgodzić się z poglądem, żeprzy ewentualnych próbach ustalenia treści poszczególnych zasad współżycia społecznego należy przyjąć jako punkt wyjścia te wartości społecznie, których poszanowanie jest niezbędne dla poprawnego ukształtowania stosunków międzyludzkich. Oznacza to w konsekwencji, że zwłaszcza wysoko cenione właściwości czy przymioty, jak np. szlachetność czy bohaterstwo, powinny ustąpić zwyczajnej przyzwoitości oraz standardowym regułom, kształtującym kontakty interpersonalne ${ }^{55}$.

Ustalając więc znaczenia zasad współżycia społecznego konieczne jest odwołanie się do pozanormatywnego systemu wartości, który eksponuje cenione w świadomości społecznej normy pozaprawne ${ }^{56}$. Na szczególną zaś uwagę w tym zakresie zasługują normy moralne, które - jak zaznaczono w orzecznictwie - „(...) pozostają w zasadniczym związku z zasadami współżycia społecznego" ${ }^{\prime 57}$. Ponadto, nawiązując do wartości konstytucyjnych, w judykaturze podniesiono także, że: „(...) odwołanie się do zasad współżycia społecznego oznacza odwołanie się do idei słuszności w prawie i do powszechnie uznawanych wartości w kulturze naszego społeczeństwa. Ujmując rzecz ogólnie - jak kontynuowano - można przyjąć, że przez zasady współżycia społecznego należy rozumieć podstawowe zasady etycznego i uczciwego postępowania" 58 . Wobec powyższych ustaleń pojawia się zatem pytanie - czy sąd powinien konkretnie wskazać, jaka zasada współżycia społecznego została naruszona w świetle okoliczności faktycznych rozpoznawanej sprawy, czy też - nie dokonując jej swoistej proklamacji - może poprzestać na ogólnym stwierdzeniu, że zachowanie

${ }_{55}$ T. Sokołowski, [w:] A. Kidyba (red.), Kodeks cywilny. Komentarz. Część ogólna. Tom I, , Warszawa 2012, s. 50.

56 A. Bierć, Zarys prawa prywatnego. Część ogólna, Warszawa 2012, s. 64.

57 Wyrok SN z dnia 9 grudnia 2009 r., IV CSK 290/09, LEX nr 560607.

58 Wyrok SN z dnia 23 maja 2013 r., IV CSK 660/12, LEX nr 1365725. 
nieletniego pozostawało $\mathrm{w}$ sprzeczności z przyjętymi powszechnie zasadami współżycia społecznego ${ }^{59}$ ?

Odnosząc powyższe uwagi na płaszczyznę ustawy o postępowaniu $\mathrm{w}$ sprawach nieletnich, można również stwierdzić, że pojęcie zasad współżycia społecznego stwarza możliwość dowolnego manipulowania tym określeniem ${ }^{60}$, co z kolei może prowadzić do naruszenia zasady praworządności ${ }^{61}$.Interpretacja generalnych klauzul odsyłających zawiera bowiem elementy subiektywnej wykładni, zależnej od indywidualnych preferencji. Stąd też, wydaje się, że nawet wówczas, gdy sąd rodzinny starałby się w jak najlepszy sposób oddać preferencje społeczne, to i tak „obiektywnośćc ta oparta jest na intuicyjnej oraz uwikłanej we własne oceny wiedzy sędziego ${ }^{62}$. Odesłanie do ,już" ukształtowanych norm społecznie aprobowanych oznacza najczęściej, że dokonywane przez sąd wartościowanie pozostaje tylko - w założeniu - ponadjednostkowe oraz intersubiektywne ${ }^{63}$.

${ }^{59}$ Warto wspomnieć, że w orzecznictwie cywilistycznym nie ma zgodności poglądów w tym zakresie. Postulat, aby sąd, rozstrzygając sprawę na podstawie art. 5 k.c., sformułował konkretną zasadę współżycia, na którą się powołuje, był formułowany w czasach PRL-u (zob. np. wyrok SN z dnia 5 maja 1964 r., I PR 159/64, OSN 1965, nr 1, poz. 19) i sporadycznie również w okresie III Rzeczypospolitej, por. np. wyrok SN z dnia 14 października 1998 r., II CKN 928/97, OSNC 1999, nr 4, poz. 75: „Powoływanie się na naruszenie zasad współżycia społecznego wymaga wskazania, jaka konkretnie zasada została naruszona, oraz wskazania pełnej treści powoływanej zasady". W judykaturze nie brakuje przy tym poglądów, wskazujących również, że treść zasad współżycia społecznego nie jest zdefiniowana. Por. np. wyrok SN z dnia 28 listopada 2001 r., IV CKN 1756/00, LEX nr 80259. Podobne stanowisko organ ten wyraził także w późniejszych orzeczeniach - por. wyrok SN z dnia 6 stycznia 2009 r., I PK 18/08, OSN 2010, nr 13-14, poz. 156 oraz wyrok SN z dnia 16 czerwca 2009 r., I CSK 522/08, LEX nr 518132; por. K. Pietrzykowski, [w:] K. Pietrzykowski (red.), Kodeks cywilny. Tom I. Komentarz. Art. 1-449, Warszawa 2013, s. 43-44.

${ }^{60}$ M. Korcyl-Wolska, Postępowanie w sprawach..., s. 47.

${ }^{61}$ Z. Sienkiewicz, System sądowych środków..., s. 96.

${ }^{62}$ L. Leszczyński, Stosowanie generalnych klauzul odsyłających, Kraków 2001, s. 430.

${ }^{63}$ Por. uwagi L. Leszczyńskiego, L. Leszczyński, Tworzenie generalnych klauzul odsyłajacych, Lublin 2000, s. 27; por. także S. Grzybowski, Wypowiedź normatywna oraz jej struktura formalna, "Zeszyty Naukowe Uniwersytetu Jagiellońskiego" 1961, t. XXXIX, s. 41. W tym miejscu warto również wspomnieć, iż Trybunał Konstytucyjny - wypowiadając się o rozważanej klauzuli generalnej - w kontekście art. 5 k.c. - uznał, że to ogólnikowe sformułowanie nie stwarza jednak zagrożenia dla przewidywalności orzeczenia sądu. Nieprzewidywalność „linii oceniania” zachodzi zaś - jak stwierdził Trybunał Konstytucyjny w przypadku, gdy: 1) przesłanki rozumienia tej klauzuli generalnej posiadałyby nie tylko obiektywny, lecz i subiektywny charakter, 2) klauzula ta nie stwarzałaby gwarancji, że jej interpretacja stanie się jednolita i ścisła, zapewniając tym samym możliwość przewidywania rozstrzygnięcia, 3) brzmienie tej klauzuli pozwalałoby wyprowadzić uprawnienia 
Nadanie określonej treści naruszeniu zasad współżycia społecznego przez osobę nieletnią wydaje się prima facie pożądane z perspektywy gwarancyjnej funkcji prawa. W przeciwnym wypadku nie sposób byłoby uniknąć niezręcznego pytania - czy sędziowie nie działają w tym zakresie w sposób intuicyjno-przypadkowy? Ewentualna propozycja wykładni tego określenia wiązałaby się $\mathrm{w}$ istocie jedynie $\mathrm{z}$ kazuistycznym wyróżnieniem zachowań, świadczących o naruszeniu wspomnianych zasad. Przykładowo, mogłyby one polegać na: trzymaniu nóg na ławce szkolnej, ignorowaniu uwag nauczyciela, przedrzeźnianiu bądź wyśmiewaniu się z nauczyciela lub innych osób, używaniu wulgarnych słów, jak również podejmowaniu prowokacyjnych, obyczajowo niestosownych zachowań ${ }^{64}$.

Z drugiej jednak strony, wydaje się, że istotną przeszkodą w skatalogowaniu tych zasad jest pewna trudność w ustaleniu czy dane zachowanie jest naruszeniem zasad współżycia społecznego, czy też stanowi „nieskatalogowany", odrębny przejaw demoralizacji65. Poza tym, czynnikiem uniemożliwiającym ich ścisłe określenie jest czasowo-miejscowa zmienność tych zasad, która - o czym warto wspomnieć - pozwala zachować pewną elastyczność w stosowaniu prawa ${ }^{66}$.

Od zasygnalizowanych trudności interpretacyjnych nie są również wolne pozostałe, ustawowo zadekretowane, objawy demoralizacji ${ }^{67} . W$ tym miejscu należałoby w szczególności wspomnieć, że traktowanie „popełnienia czynu zabronionego", jako przejawu demoralizacji, generuje także istotne wątpliwości. Mając bowiem na względzie legalną definicję czynu

prawotwórcze sądu do samoistnego nadawania nowej treści niniejszemu zwrotowi. Por. wyrok Trybunału Konstytucyjnego z dnia 17 października 2000 r., SK 5/99, OTK 2000, nr 7, poz. 254. Szczególne wątpliwości w tym zakresie może wzbudzać wyrażone założenie o „obiektywności” rozumienia klauzuli generalnej, odwołującej się do zasad współżycia społecznego. Wydaje się, że postulowana „obiektywnośćc interpretacyjna mogłaby - w kontekście tego rodzaju zwrotów nieostrych - być jedynie rozumiana jako konieczność uwzględnienia dotychczasowej wykładni sądowej w tym zakresie. Por. L. Leszczyński, Stosowanie generalnych..., s. 430-431.

${ }^{64}$ V. Konarska-Wrzosek, Prawny system..., s. 56.

${ }^{65} \mathrm{~W}$ doktrynie podkreśla się, że zasadniczo wszystkie zachowania naganne, jak np.: kłamstwo, nieposzanowanie starszych, kolegów, nieposłuszeństwo można nazwać demoralizacją. Por. B. Kowalska-Ehrlich, Młodzież nieprzystosowana..., s. 19. Stąd też, niektórzy autorzy stwierdzaja że naruszeniem zasad współżycia społecznego będą tylko takie zachowania, które są rażące sprzeczne z nomami moralno-obyczajowymi. Por. A. Krukowski, [w:] A. Krukowski (red.), Ustawa o postępowaniu..., s. 36.

${ }^{66}$ A. Wolter, J. Ignatowicz, K. Stefaniuk, Prawo cywilne. Zarys części ogólnej, Warszawa 2000, s. 78.

${ }^{67}$ P. Kobes, Prawny system przeciwdziałania..., s. 117-136. 
karalnego $^{68}$, występującego w charakterze drugiej, obok demoralizacji, przesłanki stosowania niniejszej regulacji prawnej, nie sposób byłoby przynajmniej prima facie - uniknąć kontrowersji, czy np. dopuszczenie się kradzieży będącej jednocześnie czynem zabronionym ${ }^{69}$ oraz czynem karalnym (w świetle ustawy o postępowaniu w sprawach nieletnich) stanowi $w$ indywidualnej ocenie - bardziej symptom demoralizacji nieletniego, czy też (zgodnie z wolą ustawodawcy)okoliczność uzasadniająca wszczęcie postępowania o czyn karalny ${ }^{70}$.Warto również nadmienić, że stosowanego objaśnienia ustawowego wymagałoby, wspomniane powyżej pojęcie „czynu zabronionego" (art. 4 § 1u.p.n.). Z brzmienia przepisów komentowanej regulacji wynika bowiem, że posiada ono w istocie odmienny zakres przedmiotowy, w zależności od tego czy sprawcą jest osoba powyżej, czy poniżej lat 13. Niezależnie od powyższych ustaleń, wypadałoby również w tym miejscu stwierdzić, iż popełnienie przez nieletniego czynu zabronionego stanowi w istocie szczególny przejaw demoralizacji, świadczący wyraźnie o jego aspołecznej postawie i lekceważącym stosunku do ogólnie aprobowanych standardów postępowania. Stąd też, w kontekście niniejszej okoliczności ustawowej, powstaje wątpliwość czy wobec tego rodzaju zachowań ustawodawca nie powinien jednak przewidzieć specjalnych - niewykluczone, iż bardziej rygorystycznych - środków reakcji od tych, które wynikają z ustawy o postępowaniu w sprawach nieletnich. $\mathrm{Z}$ tego też względu wydaje się, iż de lege ferenda pożądane byłoby poszukiwanie nowych form oddziaływania wobec nieletnich, które w praktyce

${ }^{68}$ Zgodnie z art. 1§2 u.p.n. „Ilekroć w ustawie jest mowa o: (...) 2) „czynie karalnym” rozumie się przez to czyn zabroniony przez ustawę jako: a) przestępstwo lub przestępstwo skarbowe albo b) wykroczenie określone w art. 51, art. 69, art. 74, art. 76, art. 85, art. 87, art. 119, art. 122, art. 124, art. 133 lub art. 143 Kodeksu wykroczeń".

${ }^{69}$ Należy podkreślić, iż pojęcie „czynu zabronionego” będzie obejmować zachowania, odpowiadające ustawowym znamionom przestępstw stypizowanych w ustawie z dnia 6 czerwca 1997 r. - Kodeks karny (tekst jednolity, Dz. U. z 2016 r., poz. 1137) i innych ustawach, jak również przestępstwom i wykroczeniom skarbowym, określonym w ustawie z dnia 10 września 1999 r. - Kodeks karny skarbowy (tekst jednolity, Dz. U. z 2016 r., poz. 2137) oraz wykroczeniom, wynikającym z ustawy z dnia 20 maja 1971 r. - Kodeks wykroczeń (tekst jednolity, Dz. U. z 2015 r., poz. 1094) i innych ustaw. Por. P. Kobes, Prawny system przeciwdziałania..., s. 117.

${ }^{70} \mathrm{~W}$ tym miejscu należy jednak podkreślić, iż wszczęcie postępowania o czyn karalny - w świetle ustawy o postępowaniu w sprawach nieletnich - jest możliwe tylko wobec nieletnich, którzy ukończyli w chwili popełnienia czynu 13 lat - art. $1 \S 1$ pkt 2 u.p.n. Por. E. Filipowska, Postępowanie w sprawach nieletnich, Warszawa 2009, s. 41. 
stanowiłyby adekwatne i skuteczne narządzie dla procesu kształtowania ich świadomości prawnej.

Ponadto, wydaje się, że przy ocenie takich przesłanek jak: uchylanie się od obowiązku szkolnego lub kształcenia zawodowego czy używanie alkoholu lub innych środków w celu wprowadzenie się w stan odurzenia, należy przede wszystkim uwzględnić genezę tego rodzaju zjawisk. Konieczne byłoby więc wnikliwe sprawdzenie czy wspomniane postępowania nie stanowią wprost reakcji obronnej bądź „znieczuleniowej” wobec przykrych sytuacji w rodzinie ${ }^{71}$.

Poza tym, mało przejrzysta jest także linia demarkacyjna, oddzielająca dwa odrębnie wyróżnione $\mathrm{w}$ ustawie symptomy demoralizacji, w postaci ucieczki nieletniego z domu z jednej strony oraz włóczęgostwa z drugiej strony. Wydaje się bowiem, że to ostatnie stanowi następstwo częstych ucieczek z domu. Stąd też, prowadzi to do wniosku, że w praktyce stosowania omawianej regulacji prawnej mogą pojawić się wątpliwości czy dane zachowanie dziecka jest przejawem nieuzasadnionego opuszczenia domu, czy też tego rodzaju postępowanie nieletniego uległo już przekształceniu we włóczęgostwo ${ }^{72}$.

Dalsze zastrzeżenia wypadałoby również skierować wobec ustawowego sformułowania, traktującego udział w grupach przestępczych, jako jeden z objawów demoralizacji. Powyższe określenie może bowiem wzbudzać pewne asocjacje do zdefiniowanej w literaturze karnistycznej „zorganizowanej grupy przestępczej”. W ocenie A. Gaberle, wspomnianą przesłankę, wynikająca z ustawy o postępowaniu w sprawach nieletnich, trzeba jednak interpretować rozszerzająco. Za grupę przestępczą nieletnich należałoby zatem uznać również taką zbiorowość, w której nie byłoby wewnętrznych struktur, jak również wyraźnie ustalonych zasad działania ${ }^{73}$.

Ponadto, warto również zaznaczyć, iż dodatkowe kontrowersje interpretacyjne może rodzić także "otwartość” katalogu ustawowych przejawów demoralizacji. Wątpliwe pozostaje - przykładowo - czy np. przynależność do sekty czy też innych, rzekomych grup wsparcia jest podstawą

${ }^{71}$ A. Sztajner, Dziecko w rodzinie z problemem alkoholowym, „Problemy Alkoholowe” 1994, nr 6, s. 3; por. także T. Kulisiewicz, Zespół uzależnienia alkoholowego. Część I, „Problemy Alkoholowe" 1998, nr 4, s. 3.

72 Por. A. Gaberle, M. Korcyl-Wolska, Komentarz do ustawy o postępowaniu w sprawach nieletnich, Gdańsk 2002, s. 36.

${ }^{73}$ Ibidem. 
do wszczęcia postępowania w trybie ustawy o postępowaniu w sprawach nieletnich. Wydaje się, że tego rodzaju przypadki świadczą niewątpliwie o zagrożeniu dobra dziecka, zaś stosowną podstawą prawną interwencji pozostaje jednak ustawa z dnia 25 lutego 1964 r. - Kodeks rodzinny i opiekuńczy $^{74}$ wraz z przewidzianymi w nim rozwiązaniami o charakterze prewencyjnym (art. 109 k.r.o.) $)^{75}$.

\section{Uwagi końcowe}

Podsumowując dotychczasowe ustalenia należy w pierwszej kolejności zauważyć, że stricte semantyczne ujęcie demoralizacji wzbudza poważne wątpliwości. Ścisłe powiązanie tego określenia z „odejściem” od ukształtowanych w procesie socjalizacji wartości, oznaczałoby bowiem, że z zakresu niniejszego pojęcia trzeba dokonać szereg wyłączeń podmiotowych. Przede wszystkim nie odnosiłoby się ono - o czym już wspomniano - do małych dzieci, jak również względem osób wychowanych w środowiskach patologicznych, które uniemożliwiły osiągnięcie wymaganego procesu uspołecznienia. W świetle słownikowego rozumienia, przejawów demoralizacji trudno byłoby również doszukiwać się wśród osób, które posiadają wrodzone predyspozycje do podejmowania zachowań społecznie nieakceptowanych. W konsekwencji wypadałoby więc stwierdzić, że zaprezentowane ujęcie demoralizacji abstrahuje od włączenia w zakres tego pojęcia typowych przypadków zwichniętej czy też zaburzonej socjalizacji, jak również antagonistyczno-destrukcyjnych wpływów negatywnie oddziałujących na rozwój młodego człowieka ${ }^{76}$.Ponadto, kontrowersyjne zdaje się również przekonanie, że tylko nieodpowiednie wzorce ze

${ }^{74}$ Ustawa z dnia 25 lutego 1964 r. - Kodeks rodzinny i opiekuńczy, tekst jednolity, Dz. U. z 2015 r., poz. 2082.

75 P. Górecki, V. Konarska-Wrzosek, Postępowanie w sprawach nieletnich. Komentarz, Warszawa 2015, s. 42. W piśmiennictwie podkreśla się, że środków przewidziany w ustawie o postępowaniu w sprawach nieletnich nie można stosować ponadto wtedy, gdy nieletni dopuścił się czynu świadczącego o demoralizacji, lecz nie można go uznać za zdemoralizowanego (np. działając w stanie wyższej konieczności czy w obronie koniecznej). Zob. F. Zedler, Postępowanie opiekuńczo-wychowawcze, Warszawa 1986, s. 16; A. Haak-Trzuskawska, H. Haak, Ustawa o postępowaniu w sprawach nieletnich, Warszawa 2015, s. 18.

${ }^{76}$ Odrębne ujęcie demoralizacji, zwichniętej socjalizacji oraz socjalizacji antagonistyczno - destrukcyjnej proponował Cz. Czapów, podkreślając w ten sposób odmienność wskazanych określeń. Por. Cz. Czapów, Wychowanie..., s. 140-141. 
środowiska zewnętrznego stanowią powód dla zachwiania dotychczas respektowanych wartości społecznych. Wydaje się, że tego rodzaju decyzja nieletniego może również wynikać z jego własnych, autonomicznych przekonań oraz przemyśleń. Z powyższych uwag wynika zatem, że proces demoralizacji nie posiada charakteru samoczynnego, lecz jest on $\mathrm{w}$ istocie determinowany wieloma czynnikami.

Zasygnalizowanych wątpliwości nie łagodzą przy tym doktrynalne wysiłki, próbujące objaśnić znaczenie demoralizacji .Opracowane przez naukę przedmiotu modelowe ujęcia tego zjawiska pozostają często w nurcie socjologicznym lub psychologiczno-socjologicznym, co niewątpliwie utrudnia wypracowanie jednolitego stanowiska w tym zakresie. W literaturze podkreśla się przy tym, że niezależnie od tego czy definicje te uwzględniają wyłącznie elementy socjologiczne, czy również zwraca się $\mathrm{W}$ nich uwagę na zaburzony stan osobowości nieletniego ${ }^{77}$, są one narażone na zarzut zbytniego relatywizmu i dowolności ocen. Subiektywny system kwalifikowania określonych zachowań jako przejawów demoralizacji uznaje się przede wszystkim za mało gwarancyjny, co w konsekwencji groziłoby nierespektowaniem praw dziecka ${ }^{78}$. Wyrażone uwagi dotyczą również kwestii ustawowej oceny stopnia demoralizacji. Wydaje się bowiem, że trudno byłoby in abstracto zgodzić się z poglądem, że - przykładowo - kilkukrotny przejaw zachowania wskazanego w 4 § 1 u.p.n. świadczy bezwarunkowo o wysokim stopniu deprawacji nieletniego ${ }^{79}$. Z powyższych ustaleń wynika zatem, że pojęcie demoralizacji pozostaje określeniem funkcjonującym na zasadach wyraźnie niejednolitej konwen-

77 Warto w tym miejscu zaznaczyć, iż m.in. na konieczność uwzględnienia osobowości nieletniego $\mathrm{w}$ ramach postępowania $\mathrm{w}$ trybie omawianej ustawy wskazuje art. $3 \S 2$ u.p.n.: „W postępowaniu z nieletnim bierze się pod uwagę osobowość nieletniego, a w szczególności wiek, stan zdrowia, stopień rozwoju psychicznego i fizycznego, cechy charakteru, a także zachowanie się oraz przyczyny i stopień demoralizacji, charakter środowiska oraz warunki wychowania nieletniego".

${ }^{78}$ Do tego rodzaju przypadków dochodzi wówczas, gdy w proponowanych definicjach demoralizacji następuje relatywizowanie norm zachowania do wzorców propagowanych przez określone podmioty np. organizacje młodzieżowe, grupę koleżeńską. Por. A. Grześkowiak, Postępowanie w sprawach nieletnich (polskie prawo nieletnich), Toruń 1986, s. 49 i n. oraz literatura tam podana.

79 Por. w tym zakresie wyrok SA we Wrocławiu z dnia 6 listopada 2012, II AKa 314/12, Legalis nr 745740, w którym stwierdzono, że: „Czterokrotna karalność oskarżonego w bardzo krótkim okresie czasu, oznacza, że stopień jego demoralizacji, pomimo młodego wie$\mathrm{ku}$, jest wysoki". 
cji, niepozwalającej tym samym na skonkretyzowanie jego ostatecznej treści ${ }^{80}$.

Na podstawie przedstawionych rozważań wypada również stwierdzić, że wprawdzie objawowe - wynikające z przepisów ustawy o postępowaniu w sprawach nieletnich -określenie demoralizacji jest niedoskonałe $\mathrm{z}$ teoretycznego punktu widzenia, to jednak - z perspektywy praktyki - pozostaje ono ujęciem najbardziej operatywnym. Pominięcie elementów psychologicznych, jak również etiologicznych w przepisach normatywnych wydaje się przy tym uzasadnione koniecznością zapewnienia sądowi mniej skomplikowanego trybu wyodrębnienia tych przypadków, które wymagają podjęcia stosownej interwencji wychowawczej ${ }^{81}$.

Słowa kluczowe: nieletni, demoralizacja, czyn karalny, odpowiedzialność sprawców nieletnich

\section{Bibliografia:}

Adamik K., Lisiecki M., Ocena stosowania niektórych środków wychowawczych i poprawczych przewidzianych w ustawie o postępowaniu w sprawach nieletnich, „Przegląd Policyjny” 1997, nr 3.

Artymoniak G., Prawo nieletnich sprawców czynów zabronionych do bezstronnego sadu - zagadnienia wybrane, [w:] A. Michalska-Warias, I. Nowikowski, J. Piórkowska-Flieger (red.), Teoretyczne i praktyczne wspótczesnego prawa karnego. Ksiegga jubileuszowa dedykowana Profesorowi Tadeuszowi Bojarskiemu, Lublin 2011.

Bielecki E., Wybrane problemy patologii przystosowania społecznego i pedagogiki resocjalizacyjnej, Bydgoszcz 1983.

Bieńkowska E., Walczak-Żochowska A., Postępowanie w sprawach nieletnich. Komentarz, Warszawa 2003.

Bierć A., Zarys prawa prywatnego. Część ogólna, Warszawa 2012.

Błachut J., Gaberle A., Krajewski K., Kryminologia, Gdańsk 2007.

Chodun A., Gomułowicz A., Skoczylas A., Klauzule generalne i zwroty niedookreślone w prawie podatkowymi administracyjnym. Wybrane zagadnienia teoretyczne i orzecznicze, Warszawa 2013.

Cichy A., Szyjko C., Nieletni jako przestępca w XXI wieku - studium uwarunkowań społeczno-prawnych, Warszawa 2014.

\footnotetext{
80 A. Grześkowiak, Postępowanie w sprawach..., s. 52.

81 Z. Sienkiewicz, System sąowych środków..., s. 95.
} 
Cieślak M., O wytycznych Sadu Najwyższego z 16.X. 1957 r. w sprawie wymiaru kary, „Palestra” 1958, nr 3-4.

Cieślak M., Wytyczne Sądu Najwyższego w sprawie wymiaru kary a problem społecznego niebezpieczeństwa (w związku z głosem sędziego Szerera), "Palestra” 1958, nr 7-8.

Czapów C., Wychowanie resocjalizujące, Warszawa 1978.

Derlatka M., Przestępczość jako skutek wadliwej socjalizacji w rodzinie, "Jurysta" 2013, nr 2

Dmowski S., Rudnicki S., Komentarz do kodeksu cywilnego. Księga pierwsza. Część ogólna, Warszawa 2007.

Dybowski T., Zasady wspótżycia społecznego i społeczno-gospodarcze przeznaczenia prawa a prawo własności, „Nowe Prawo” 1967, nr 6.

Eichstaedt K., Postepowanie przed sadem w sprawach nieletnich, Warszawa 2008.

Filipowska E., Postepowanie w sprawach nieletnich, Warszawa 2009.

Firkowska- Mankiewicz A., Czynniki biopsychiczne a przestępczość nieletnich, Warszawa 1972.

Gaberle A. , Patologia społeczna, Warszawa 1993.

Gaberle A., Korcyl-Wolska M., Komentarz do ustawy o postępowaniu w sprawach nieletnich, Gdańsk 2002.

Gaberle A., Podstawowe problemy nowej ustawy o nieletnich (na przykładzie projektu ustawy Prawo nieletnich z 2008 r., [w:] T. Bojarski, K. Nazar-Gutowska, A. Michalska-Warias, J. Piórkowska-Flieger, A. Sośnicka, M. Szwarczyk, D. Firkowski (red.), Problemy reformy postępowania w sprawach nieletnich, Lublin 2008.

Górecki P., Stachowiak S., Ustawa o postępowaniu w sprawcach nieletnich. Komentarz, Warszawa 2010.

Górecki P., V. Konarska-Wrzosek V., Postępowanie w sprawach nieletnich. Komentarz, Warszawa 2015.

Gromek K., Komentarz do ustawy o postepowaniu w sprawach nieletnich, Warszawa 2004.

Grześkowiak A., Postępowanie w sprawach nieletnich (polskie prawo nieletnich), Toruń 1986.

Grzybowski S., Struktura i treść przepisów prawa cywilnego odsyłających do zasad wspótżycia społecznego, "Studia Cywilistyczne” 1965, nr 6.

Grzybowski S., Wypowiedź normatywna oraz jej struktura formalna, "Zeszyty Naukowe Uniwersytetu Jagiellońskiego" 1961, t. XXXIX.

Haak-Trzuskawska A., Haak H., Ustawa o postępowaniu w sprawach nieletnich, Warszawa 2015.

Harasimiak G., Demoralizacja jako podstawowe pojęcie postępowania z nieletnimi. Analiza i wnioski, Szczecin 2001.

Hołyst B. , Kryminologia, Warszawa 2004.

Kobes P., Prawny system przeciwdziałania demoralizacji i przestępczości nieletnich, Warszawa 2011. 
Kołakowska-Przełomiec H., Postępowanie w sprawach nieletnich, „Państwo i Prawo" 1983, nr 6.

Kołakowska-Przełomiec H., Zagadnienie profilaktyki przestępczości nieletnich w świetle badań kryminologicznych, „Studia Prawnicze” 1972, nr 34.

Konarska-Wrzosek V., Ochrona nieletnich przed demoralizacja i przestępczościa w ujęciu ustawy o postępowaniu w sprawach nieletnich, "Państwo i Prawo" 1999, nr 5.

Konarska-Wrzosek V., Prawny system postępowania z nieletnimi, Warszawa 2013.

Konarska-Wrzosek V., Zjawisko demoralizacji i przestępczości nieletnich w świetle danych statystycznych, "Acta Universitatis Nicolai Copernici” 1996, z. 307.

Konopnicki J., Niedostosowanie społeczne, Warszawa 1971.

Konopnicki J., Powodzenia i niepowodzenia w szkole, Warszawa 1966.

Korcyl-Wolska M., Postępowanie w sprawach nieletnich w Polsce, Kraków 2001.

Kossowska A., Funkcjonowanie kontroli społecznej, analiza kryminologiczna, Warszawa 1992.

Kowalska-Ehrlich B., Młodzież nieprzystosowana społecznie a prawo, Warszawa 1988.

Kozłowski P., Dynamika demoralizacji i przestępczości nieletnich - analiza statystyczna zjawiska i propozycja indywidualnych rozwiązan, „Przegląd Więziennictwa Polskiego" 2010, nr 69.

Krakowski L., Zasady współżycia społecznego w stosunkach prawa pracy w PRL, Warszawa 1970.

Krukowski A., [w:] A. Krukowski (red.), Ustawa o postępowaniu w sprawach nieletnich. Komentarz, Warszawa 1984.

Kulisiewicz T., Zespót uzależnienia alkoholowego. Część I, „Problemy Alkoholowe" 1998, nr 4.

Laskowski A., Rejzner A., Tokarczyk E., Demoralizacja i przestępczość dzieci i młodzieży. Atlas, Warszawa 1996.

Leszczyński J., Z problematyki prewencji ogólnej, „Palestra” 1974, nr 11.

Leszczyński L., Stosowanie generalnych klauzul odsyłających, Kraków 2001.

Leszczyński L., Tworzenie generalnych klauzul odsyłajacych, Lublin 2000.

Lewandowski S., Machińska H., [w:] A. Malinowski (red.), Logika dla prawników, Warszawa 2002.

Makowski A., Niedostosowanie społeczne młodzieży i jej resocjalizacja, Warszawa 1994.

Mały Rocznik Statystyczny, Warszawa 2006.

Mały Rocznik Statystyczny, Warszawa 2009.

Mały Rocznik Statystyczny, Warszawa 2010.

Mały Rocznik Statystyczny, Warszawa 2011.

Mały Rocznik Statystyczny, Warszawa 2012

Mały Rocznik Statystyczny, Warszawa 2013.

Mały Rocznik Statystyczny, Warszawa 2014.

Mały Rocznik Statystyczny, Warszawa 2016. 
Mały słownik języka polskiego, S. Skorupka, N. Auderska, Z. Łempicka (red.), Warszawa 1969.

Niewiadomska I., Polakiewicz P., Osobowość sprawcy a popetnienie przestępstwa, [w:] J. Świtka, M. Kuć, I. Niewiadomska (red.), Osobowość przestępcy a proces resocjalizacji, Lublin 2005.

Nowacki J., Luki w prawie. Ideologia, „Studia Prawno-Ekonomiczne” 1970, t. VI.

Ostrihańska Z., Kryteria nieprzystosowania społecznego dzieci i młodzieży , „Archiwum Kryminologii" 1972, nr 5.

Ostrowska K., Wójcik D., Teorie kryminologiczne, Warszawa 1986.

Patulski W., Postępowanie w sprawach nieletnich, „Nowe Prawo” 1983, nr 1.

Pietrzykowski K., [w:] K. Pietrzykowski (red.), Kodeks cywilny. Tom I. Komentarz. Art. 1-449, Warszawa 2013.

Praktyczny słownik współczesnej polszczyzny. T. 8, H. Zgółowska (red.), Poznań 1994

Przetacznikowa M., Susłowska M., Wybrane zagadnienia psychologii kliniczno wychowawczej dzieci i młodzieży, [w:] Psychologia kliniczna, (red.) A. Lewicki, Warszawa 1969

Radwański Z., M. Zieliński, [w:] M. Safjan (red.), System Prawa Prywatnego. Prawo cywilne - czesść ogólna. Tom I, Warszawa 2012.

Ratajczak A., Materialnoprawne problemy ustawy o postępowaniu w sprawach nieletnich, „Państwo i Prawo” 1983, nr 2.

Siemaszko A. , Granice tolerancji. O teoriach zachowań dewiacyjnych, Warszawa 1993.

Sienkiewicz Z., Sporne kwestie wokót pojęcia demoralizacji i nieprzystosowania spotecznego, [w:] T. Bojarski (red.), Postępowanie z nieletnimi. Orzekanie i wykonywanie środków wychowawczych poprawczych, Lublin 1988.

Sienkiewicz Z., System sądowych środków wobec nieletnich $w$ prawie polskim, Wrocław 1989.

Skorny Z., Koncepcje socjalizacji w literaturze naukowej, „Psychologia Wychowawcza" 1975, nr 3.

Stownik języka polskiego. T. I, M. Szymczak (red.), Warszawa 1978.

Sokołowski T., [w:] A. Kidyba (red.), Kodeks cywilny. Komentarz. Część ogólna. Tom I, Warszawa 2012

Stanowska M., Walczak-Żochowska A., Wierzbowski K., Uwagi o profilu ustawy o postępowaniu z nieletnimi. (Zagadnienia materialnoprawne i procesowe), „Państwo i Prawo" 1983, nr 6.

Stańdo-Kawecka B., Prawo karne nieletnich - od opieki do odpowiedzialności, Warszawa 2007.

Strzembosz A., Postępowanie w sprawach nieletnich w prawie polskim, Lublin 1984.

Swół J., Polski system przeciwdziałania demoralizacji i przestępczości nieletnich. Zarys problematyki, „Przegląd Policyjny” 2014, nr 2. 
Szmiłyk J., Przeciwdziałanie demoralizacji dzieci i młodzieży w świetle przepisów ustawy o postępowaniu $w$ sprawach nieletnich, www.google.pl/url? sa=tE $r c t=j$ $\mathcal{E} q=\mathcal{E} e s r c=s \mathcal{E} s o u r c e=w e b \mathcal{E} c d=4 \mathcal{E} v e d=w 0 C D w Q F j A D \mathcal{E} u r l=\mathrm{http} \% 3 \mathrm{~A} \% 2 \mathrm{~F} \% 2$ Fwww.eduforum.pl\%2Fmodules.php\%3Fname\%3DPublikacje\%26d_op \%3Dgetit\%26lid\%3D2867\&ei=PIUAU7X5C6r9ywPZ0IHQCg\&usg=AFQj CNHUbUUDvL9iywB1nVkeaoGMIRLw\&bvm=bv.61535280,d.bGQ [dostęp: 02.07.2015 r.]

Szpunar A., Stosowania art. 5 Kodeksu cywilnego w sprawach o prawa stanu, „Państwo i Prawo" 1981, nr 6.

Sztajner A., Dziecko w rodzinie z problemem alkoholowym, „Problemy Alkoholowe" 1994, nr 6.

Sztompka P., Socjologia. Analiza społeczeństwa, Kraków 2002.

Tyburska A. Wpływ dysfunkcyjności rodziny na rozwój dzieci i młodzieży, „Przegląd Policyjny" 1997, nr 4.

Urban B., Zaburzenia w zachowaniu i przestępczość młodzieży, Kraków 2000.

Wolter A., Ignatowicz J., Stefaniuk K., Prawo cywilne. Zarys części ogólnej, Warszawa 2000.

Wójcik K., Klauzule generalne a pojęcia prawne i prawnicze (zasady prawa i społeczne niebezpieczeństwo czynu), "Studia Prawno-Ekonomiczne” 1990, t. XLV.

Wójcik K., Klauzule generalne jako zwroty wieloznaczne i oceny, „Studia PrawnoEkonomiczne" 1988, t. XLI.

Zedler F., Postępowanie opiekuńczo-wychowawcze, Warszawa 1986.

\section{MORAL CORRUPTION AS A CONTROVERSIAL CONCEPT. COMMENTS IN THE CONTEXT OF THE ACT ON PROCEEDINGS IN JUVENILE CASES}

\section{S u m m a r y}

Stating the signs of moral corruption is one of the grounds for the intervention of the family court, as provided for in the Act on proceedings in juvenile cases. Despite the importance of this concept for the application of this regulation, the legislator has not defined moral corruption directly, limiting themselves only to sample enumeration of unacceptable behaviours of the minor which may be indicative of the existence of this premise. The performed analysis shows that from a theoretical point of view this concept is indeed flawed but at the same time - from the perspective of practice - it remains the most operative.

Keywords: minor, moral corruption, punishable offence, liability of juvenile offenders 


\section{ДЕМОРАЯИЗАЦИЯ КАК СПОРНОЕ ПОНЯТИЕ. ЗАМЕЧАНИЯ НА ФОНЕ ЗАКОНА О РАЗБИРАТЕЛЬСТВЕ В ДЕЛАХ НЕСОВЕРШЕННОЯЕТНИХ}

P е 3 го м е

Обнаружение признаков деморадизации является одной из основных причин для вмешательства суда по семейным делам, которые предусмотрено в Законе о разбирательстве в делах несовершеннолетних. Несмотря на важность этого понятия для процесса применения этого закона, законодатель не определил что такое деморализация, ограничившись лишь на примерном учете неправильных поведений несовершеннолетнего, которое могут указывать на возникновение этого состояния. Анализы показывают, что концепция с теоретической точки зрения является несовершенной, но в то же время - с практической точки зрения - это понятие остается самым оперативным.

Кдючевые слова: несовершеннолетний, деморализация, уголовное преступление, ответственность виновных несовершеннолетних 